\title{
Metode Brainstorming dan Media Audiovisual Dalam Upaya Mengedukasi Kader Untuk Secara Mandiri Mengenali dan Mengelola Stunting di Desa Larike Kabupaten Maluku Tengah
}

\author{
Khartini Kaluku1, Santi Aprilian Lestaluhu², Martha Puspita Sari ${ }^{* 3}$ \\ 1,2,3Jurusan Gizi Politeknik Kesehatan Kemenkes Maluku, Jalan Laksdya Leo Wattimena, Ambon \\ *e-mail: kalukukhartini@gmail.com ${ }^{1}$, santiaprilian09@gmail.com ${ }^{2}$, martha.puspita6@gmail.com ${ }^{3}$
}

\begin{abstract}
Stunting is a condition when a person's height is known to be shorter when compared to someone else's age. Stunting rate in Indonesia is high, straight line with poor nutrition. The purpose of this community service is to increase knowledge of stunting through health counseling methods and handle independently through cadre assistance. This method begins with brainstorming and Focus Group Discussion (FGD) followed by training, distribution of leaflets, and screening of video stunting to Posyandu cadres accompanied by nutrition assistance as much as $3 x$ visits in the context of independent handling of stunting for toddlers. The results obtained that there is an increase in knowledge after brainstorming and playback of audiovisual media through counseling using these media using the Wilcoxon test with a p-value of 0.00. The conclusion is that the method of brainstorming and audiovisual media is an effective media as an alternative to educating cadres and being able to recognize and manage stunting independently.
\end{abstract}

Keywords: Audiovisual, brainstorming, cadre, stunting

\begin{abstract}
Abstrak
Stunting adalah suatu keadaan bila tinggi badan seseorang diketahui lebih pendek jika dibandingkan dengan tinggi badan orang lain yang sebaya. Angka stunting di Indonesia termasuk tinggi bergaris lurus dengan angka gizi buruk. Tujuan pengabdian masayarakat ini untuk meningkatkan pengetahuan tentang stunting melalui penyuluhan kesehatan dan melakukan penanganan secara mandiri melalui pendampingan kader. Metode ini diawali dengan brainstorming dan Focus Group Discussion (FGD) dilanjutkan dengan pelatihan, pembagian leaflet dan pemutaran video stunting kepada Kader Posyandu disertai pendampingan gizi sebanyak 3x kunjungan dalam rangka penanganan mandiri stunting pada balita. Lokasi pengabdian masyarakat dilakukan di Desa Larike, Kecamatan Leihitu Barat, Kabupaten Maluku Tengah. Hasil yang didapatkan bahwa terdapat peningkatan pengetahuan setelah brainstorming dan pemutaran media audiovisual melalui penyuluhan menggunakan media tersebut menggunakan uji Wilcoxon dengan palue 0,00. Kesimpulannya adalah metode brainstorming dan media audiovisual merupakan media yang efektif sebagai salah alternatif untuk mengedukasi kader dan mampu mengenali dan mengelola stunting secara mandiri.
\end{abstract}

Kata kunci: Audiovisual, brainstorming, kader, stunting

\section{PENDAHULUAN}

Kualitas sumber daya manusia di Indonesia menghadapi masa penurunan. Salah satu faktor yang mempengaruhi adalah adanya kekurangan gizi pada anak calon penerus bangsa. Angka gizi buruk di Indonesia terhitung tinggi dengan hasil Pemantauan Status Gizi (PSG) yang dilakukan Kementerian Kesehatan pada tahun 2016, status gizi pada balita usia 0-59 bulan menunjukkan persentase gizi buruk sebesar 3,4\% dan gizi kurang sebesar 14,4\% (Riskesdas, 2018). Salah satu dampak dari kekurangan gizi adalah terjadinya tumbuh pendek pada anak atau sering disebut dengan stunting.

Stunting merupakan malnutrisi yang terjadi secara kronis akibat dampak kumulatif dari kurangnya gizi serta terjadinya penyakit infeksi yang terjadi dalam jangka waktu panjang. Stunting pada balita ditandai dengan tinggi badan menurut umur $(\mathrm{TB} / \mathrm{U})$ atau panjang badan menurut umur (PB/U, untuk anak usia <24 bulan) kurang dari -2 SD (standar deviasi) berdasarkan median referensi. Angka Stunting di Indonesia termasuk tinggi bergaris lurus dengan angka gizi buruk. Penyebab utama dari terjadinya kasus stunting adalah kurangnya 
asupan gizi yang diterima sejak 1000 hari pertama kehidupan. Kurangnya kesadaran dan pengetahuan ibu tentang pentingnya asupan gizi dan pola pengasuhan yang baik untuk anak juga turut menjadi penyebab timbulnya stunting. Selain itu, terbatasnya akses masyarakat terhadap makanan bergizi, air bersih, sanitasi, dan fasilitas kesehatan menjadi penyebab lain terjadinya stunting (WHO, 2013).

Kejadian stunting pada janin hingga anak berusia dua tahun dapat meningkatkan angka kematian bayi dan anak serta menurunkan sistem imun. Penderita stunting mudah sakit, memiliki postur tubuh yang tidak maksimal, serta memiliki produktivitas yang rendah pada saat dewasa. Prevalensi balita pendek dan sangat pendek menurut data Riset Kesehatan Dasar (Riskesdas) 2018 adalah 30,8 \%. Hasil tersebut tidak jauh berbeda dengan prevalensi balita stunting di Maluku yaitu sebanyak 31,2\% di Kabupaten Maluku Tengah.

Tim Nasional Percepatan Penanggulangan Kemiskinan (TNP2K) menyatakan bahwa terdapat 100 kabupaten atau kota prioritas dalam penanganan stunting. Pemerintah telah meluncurkan Rencana Aksi Nasional Penanganan stunting, yang menekankan pada kegiatan konvergensi di tingkat Nasional, Daerah dan Desa, untuk memprioritaskan kegiatan intervensi Gizi Spesifik dan Gizi Sensitif pada 1.000 Hari Pertama Kehidupan hingga sampai dengan usia 6 tahun. Kegiatan ini diprioritaskan pada 100 kabupaten/kota di tahun 2018 Salah satu kabupaten tersebut terdapat di wilayah Kabupaten Maluku Tengah yaitu Desa Larike. Angka stunting di Desa Larike yang berada dalam wilayah kerja Puskesmas Larike mencapai 28 anak (34\%). Pencegahan serta penanganan stunting perlu dilakukan dengan meningkatkan pengetahuan kader. Kader merupakan anggota masyarakat yang dipilih dari dan oleh masyarakat, mau dan mampu bekerja sama dalam berbagai kegiatan kemasyarakatan secara sukarela. Kader bertanggung jawab terhadap masyarakat setempat, mereka bekerja dan berperan sebagai seorang pelaku dari sebuah system kesehatan (Rikiy, 2013).

Pemberian edukasi menggunakan ceramah secara masal telah dilakukan di desa ini, namun belum memperoleh hasil maksimal. Penelitian sebelumnya di Kalimantan Tengah menunjukkan bahwa edukasi menggunakan metode brainstorming dan audiovisual efektif dalam meningkatkan pengetahuan. Hal ini karena metode-metode tersebut mengharuskan semua kader terlibat aktif untuk menyatakan pendapat dan pengalamannya mengenai stunting. Adanya association stimulus menggunakan pengalaman atau perilaku lama dari para ibu balita menyebabkan pesan lebih mudah diterima dan dipahami oleh kader. Berdasarkan hasil penelitian Wahyurin, 2019 yang menunjukan bahwa pemberian edukasi dengan metode brainstorming dan audiovisual efektif dilakukan sehingga terdapat perbedaan pengetahuan ibu secara signifikan mengenai stunting sebelum dan sesudah dengan $p$ value $<0,05$. Oleh karena itu peneliti mencoba menerapkan pemberian edukasi dengan metode brainstorming dan audiovisual terhadap pengetahuan kader tentang stunting di Desa Larike Kabupaten Maluku Tengah.

\section{METODE}

Metode yang akan digunakan adalah brainstorming, pelatihan dan pendampingan kader menggunakan media audiovisual. Kegiatan ini dilaksanakan untuk meningkatkan kapasitas pengetahuan dan ketrampilan kader untuk pencegahan dan penanganan masalah stunting pada balita.

Tabel 1. Metode Kegiatan

\begin{tabular}{|c|c|c|c|c|c|}
\hline Kegiatan & Sasaran & Waktu & Lokasi & Prosedur & Capaian \\
\hline \multicolumn{6}{|l|}{ Pelatihan kader } \\
\hline a. $\quad$ Brainstorming & $\begin{array}{l}\text { 1) Pemerintah } \\
\& \quad \text { Saniri } \\
\text { Negeri }\end{array}$ & 1 hari & $\begin{array}{l}\text { Desa } \\
\text { Larike }\end{array}$ & $\begin{array}{l}\text { 1) Pertemuan } \\
\text { dengan } \\
\text { Pemerintah } \\
\text { Negeri, Saniri } \\
\text { Negeri, Tim }\end{array}$ & $\begin{array}{lr}\text { Terdapat } & 50 \\
\text { orang } & \\
\text { masyarakat } & \\
\text { terdiri } & \text { dari } \\
\text { perangkat } & \text { desa }\end{array}$ \\
\hline
\end{tabular}




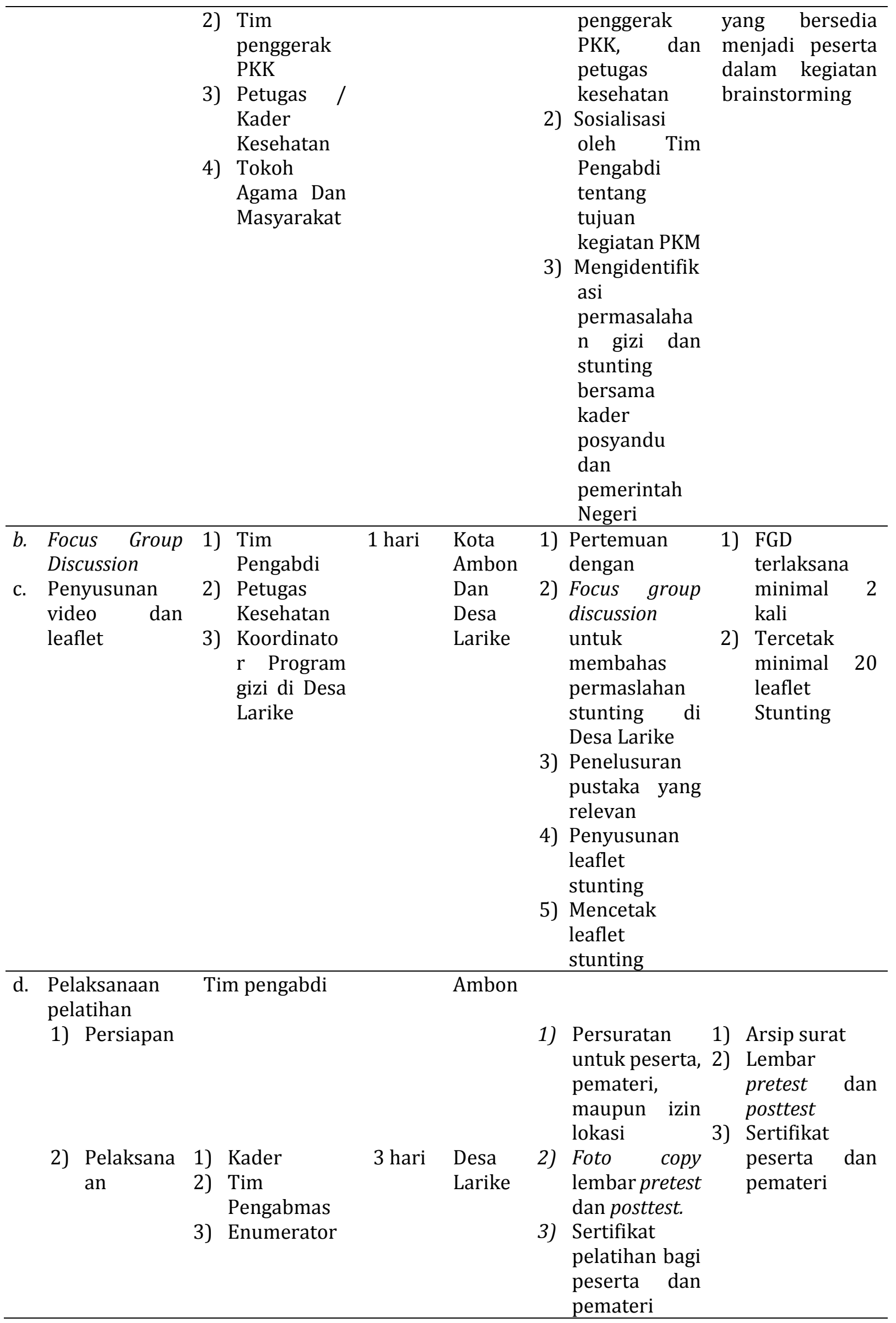


4) Menyediakan media Infocus, laptop

1) Hari I

a) Mater Brainstorm ing

b) Metode : Ceramah dan tanya jawab

c) Evaluasi pretest

d) Indikator : pengetahu an baik jika skor akhir $\geq 60$ dan kurang jika $<60$

2) Hari II

a) Materi Pencatata n dan pelaporan

b) Metode : Ceramah, tanya jawab, dan simulasi

c) Evaluasi : pretest dan posttest

d) Indikator : pengetah uan baik jika skor akhir $\geq 60$ dan kurang jika $<60$, sedangka n untuk penilaian praktiku $\mathrm{m}$ penangan an stunting
Teridentifikasiny a kendala kader dalam melaksanakan tugas di Posyandu dan pengidentifikasia n stunting sejak dini
1)Meningkatnya pengetahuan kader tentang pencatatan dan pelaporan 2)Kader dapat mempraktekk an pencatatan dan pelaporan
Kader mampu melakukan

pengukuran TB\&BB, perhitungan IMT, cara anamnesa yang terfokus pada balita, cara penyuluhan 
3) Hari III

a) Materi: pengukuran

TB\&BB, perhitungan

IMT, cara

anamnesa

yang

terfokus

pada balita,

cara

penyuluhan.

b) Metode

simulasi

c) Evaluasi

posttest

d) Indikator :

penilaian

simulasi

dengan

menilai

langsung

saat kader

memprakte

kkan,

pengukuran

TB\&BB,

perhitungan

IMT, cara

anamnesa

yang

terfokus

pada balita,

cara

penyuluhan

penilaian

mampu dan

tidak

mampu

\begin{tabular}{|c|c|c|c|c|c|c|c|}
\hline $\begin{array}{l}\text { Bantuan } \\
\text { posyandu }\end{array}$ & sarana & Kader & $1 \mathrm{kali}$ & $\begin{array}{l}\text { Desa } \\
\text { Larike }\end{array}$ & 1) & $\begin{array}{l}\text { Metode: } \\
\text { penyerahan } \\
\text { bantuan } \\
\text { sarana } \\
\text { pemeriksaan } \\
\text { di posyandu } \\
\text { balita } \\
\text { meliputi: } \\
\text { Timbangan } \\
\text { BB dan } \\
\text { Microtoise }\end{array}$ & $\begin{array}{ll}\text { Poyandu } & \\
\text { memiliki } & \text { alat } \\
\text { periksa TB dan } \\
\text { BB }\end{array}$ \\
\hline
\end{tabular}




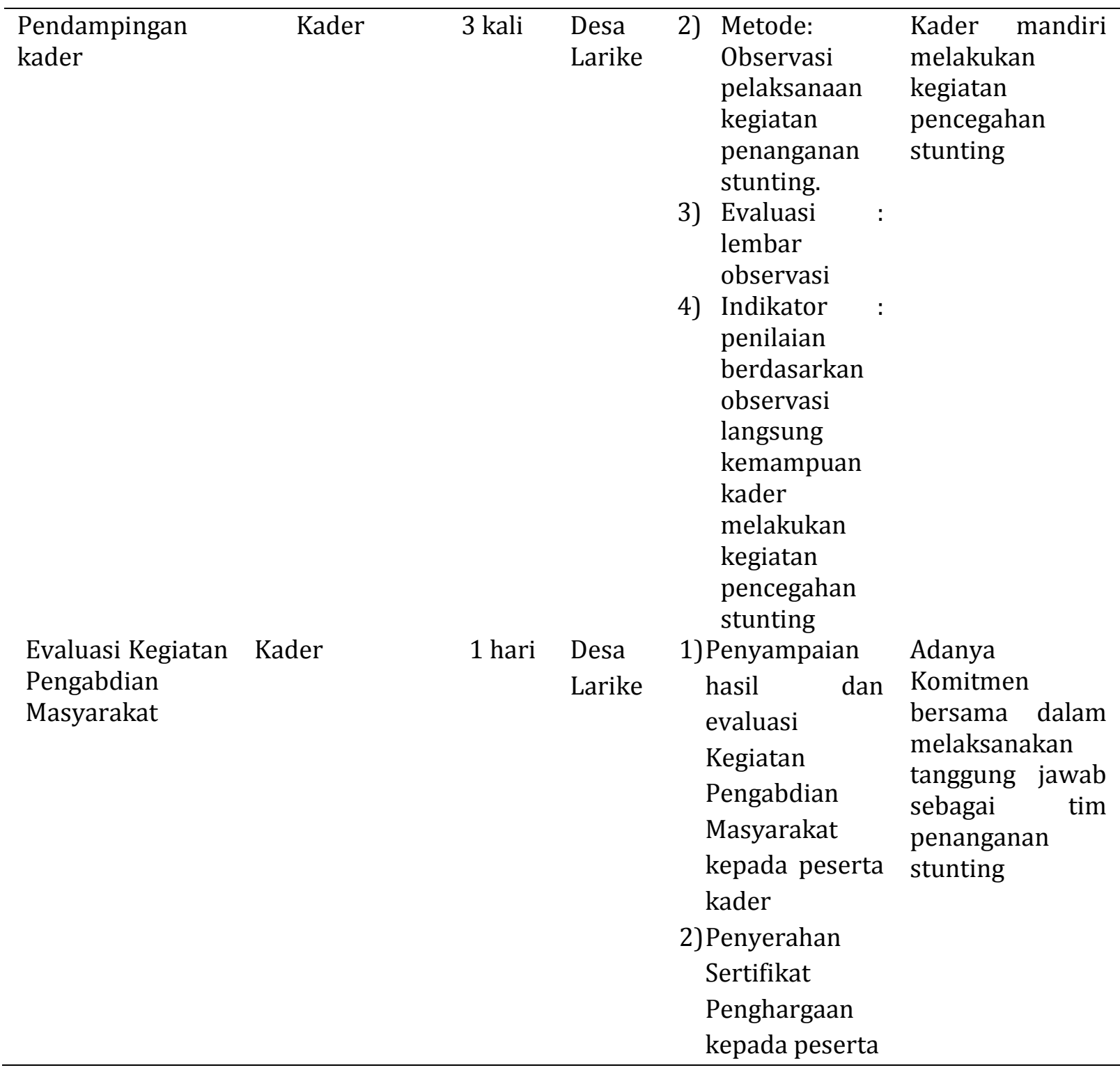

\section{HASIL DAN PEMBAHASAN}

1. Persiapan

Pengabdian Kepada Masyarakat melalui Program Kemitraan Masyarakat dilakukan dengan menerapkan metode brainstorming dan FGD untuk menggali pemahaman masyarakat tentang stunting dan kearifan lokal yang tepat untuk menangani masalah stunting di Desa Larike. Dilanjutkan dengan kegiatan pelatihan dan pendampingan untuk meningkatkan pengetahuan dan keterampilan kader di Desa Larike Kecamatan Leihitu Barat Kabupaten Maluku Tengah yang dilaksanakan selama 3 bulan mulai dari bulan Agustus sampai dengan Oktober 2019.

a. Koordinasi

Pada awal Agustus 2019, pengabdi mengurus persuratan dari Pusat Penelitian dan Pengabdian Masyarakat Poltekkes Maluku dengan sasaran Kepala Pemerintahan (Raja) Negeri Larike, Puskesmas Negeri Lima dan Kepala Pustu Desa Larike, untuk melaksanakan kegiatan pengabdian masyarakat. Dimana surat izin pengambilan data disampaikan ke masing-masing terkait pada pertengahan Agustus 2019.

Pada tahap awal Jumat, 4 Agustus 2019, Tim Pelaksana diterima pemerintah Desa Larike dan perangkat desa untuk melakukan pembahasan secara umum hingga hal-hal teknis terkait 
program pengabdian masyarakat yang Tim Pengabdi akan laksanakan serta melakukan hubungan koordinasi dengan memperkenalkan diri dan menjelaskan tentang waktu dan tujuan program pengabdian masyarakat dari Tim Pengabdi Jurusan Gizi Poltekkes Maluku di Desa Larike Kecamatan Leihitu Barat Kabupaten Maluku Tengah.

b. Persiapan Teknis

Persiapan teknis yang dilakukan Tim Pengabdi meliputi pendataan dan pembagian tugas, mempersiapkan kuesioner Pre dan Post, Spanduk, LCD, Daftar hadir peserta brainstorming, Daftar hadir peserta FGD, Daftar hadir peserta pelatihan dan Daftar hadir peserta pendampingan, Daftar hadir evaluasi kegiatan, leaflet, daftar check pelatihan dan pendampingan. Selain itu dilakukan persiapan lokasi (Balai Pertemuan Desa Larike) yang akan digunakan untuk pelaksanaan kegiatan pengabdian masyarakat di Desa Larike Kecamatan Leihitu Barat Kabupaten Maluku Tengah.

\section{Pelaksanaan Kegiatan}

Peserta yang mengikuti kegiatan brainstorming pada tanggal 2 September 2019 dan FGD pada tanggal 6 September 2019 adalah masyarakat Desa Larike sebanyak 50 orang yang terdiri dari Kepala pemerintahan beserta staf 12 orang (24\%) Saniri sebanyak 8 orang (16\%), tokoh agama dan tokoh masyarakat 8 orang (16\%), bidan desa 2 orang (4\%) dan kader kesehatan sebanyak 20 orang (40\%). Rerata umur responden adalah 33 tahun. Rata-rata tingkat Pendidikan peserta adalah SMA (56\%) SD (30\%), SMP (10\%) dan S1 (4\%).

Peserta yang mengikuti pelatihan dan pendampingan kader adalah kader kesehatan dari 3 Posyandu balita yang berjumlah 20 orang.

\section{Brainstorming}

Kegiatan Brainstorming dilaksanakan pada tanggal 2 September 2019 dengan jumlah peserta sebanyak 50 orang yang terdiri dari semua perangkat desa, tokoh agama, tokoh masyarakat, bidan desa dan kader posyandu balita. Kegiatan ini menghasilkan berbagai pendapat masyarakat Desa Larike tentang stunting, pengertian yang dipahami oleh masing-masing peserta, penyebab, gejala dan dampak yang dapat ditimbulkan. Stunting menurut masyarakat adalah balita mengalami pendek dan cenderung memiliki $I Q$ rendah yang disebabkan oleh kekurangan gizi. Keresahan warga terlihat ketika membahas kurangnya kesadaran ibu balita yang lebih memperhatikan makanan para suami daripada anaknya, berbagai tabu selama kehamilan, misalnya tidak bisa mengkonsumsi ikan dan beberapa makanan yang bersumber dari laut dengan kandungan protein yang tinggi untuk janin dalam proses $1000 \mathrm{HPK}$, masih kurang kesadaran ibu hamil dalam memeriksakan kehamilan hingga hingga proses persalinan tidak dibantu oleh tenaga kesehatan melainkan oleh dukun atau yang biasa disebut "mama biang", minimnya pengetahuan ibu tentang IMD, kolostrum dan ASI ekslusif, sehingga bayi tidak melalui proses IMD, kolostrum dibuang dan tidak maksimalnya pemberian ASI ekslusif dan juga masyarakat masih memiliki kebiasaan membuang sampah di sungai serta tidak menjaga higiene dan sanitasi di rumah. Kegiatan brainstorming sangat baik untuk menggali setiap permasalahan dan penyebab stunting yang ada di Desa Larike.

2. Foccus Group Discussion

Foccus Group Discussion merupakan keberlanjutan kegiatan pengabdian masyarakat di Desa Larike yang bertujuan untuk mengemukanan pendapat dan solusi yang ditawarkan oleh masyarakat menurut wilayah geografis dan kearifan lokal yang terdapat di Desa Larike. Kegiatan ini dilaksanakan pada tanggal 4 September 2019 yang dihadiri 50 orang peserta yang terdiri dari semua perangkat desa, tokoh agama, tokoh masyarakat, bidan desa dan kader posyandu balita. semua peserta dibagi dalam 3 kelompok yaitu kelompok pemerintahan desa, kelompok kader kesehatan dan tenaga kesehatan serta kelompok "Toga Toma". Adapun kesepakatan yang dapat disimpulkan dari pendapat ketiga kelompok diatas adalah masyarakat mendukung pemberantasan dan pencegahan stunting, masyarakat secara bersama-sama meminimalisisr penyebab stunting dengan memotong rantai masalah melalui edukasi kepada kader di Desa Larike dan mendukung setiap kegiatan yang ditawarkan oleh 
pengabdi yaitu kegiatan pelatihan dan pendampingan kader kesehatan yang merupakan ujung tombak pelaksanaan posyandu dalam pemantauan pertumbuhan dan perkembangan balita.

3. Pre dan Post Test

Peserta yang mengikuti kegiatan pekatihan pada pengabdian masyarakat adalah masyarakat yang berprofesi sebagai kader Kesehatan berjumlah 20 orang. Sebelum dilakukan pelathan dan pendampingan, peserta diberikan kuisioner pre dan post test untuk menilai kemampuan sebelum dan sesudah kegiatan. Kegiatan pre test dilaksanakan pada hari Sabtu, 9 September 2019 pukul 09.00 WIT dan post test dilaksanakan setelah pendampingan sebanyak 3x pada hari Sabtu, 24 September 2019 jam 14.00 WIT bertempat di Balai Pertemuan Desa Larike. Selama kegiatan berlangsung peserta yang hadir pada pengisian pre test, hadir juga pada post test (absen terlampir). Soal pre test dan post test terdiri atas 20 soal tentang stunting dengan pilihan jawaban menggunakan skala likert. Hasil dari pre test ini bermanfaat untuk mengetahui sejauhmana pemahaman masyarakat sebelum diberikan pelatihan dan pendampingan kader tentang stunting.

4. Pelatihan

Pada Tahap I setelah dilakukan pengisian kuisioner pre test, tim pengabdi melakukan pelatihan yang dilaksanakan pada tanggal 9 September 2019 Metode yang digunakan adalah ceramah dan tanya jawab dengan menggunakan media pendukung LCD dan wireless serta materi pelatihan menggunakan leaflet. Pemberian materi dilakukan selama 4 jam, dimulai dari jam 10.00 WIT sampai dengan jam 13.00 WIT, setelah diberikan materi kepada semua peserta, dilakukan diskusi terkait materi yang diberikan.

Kemudian tahap berikutnya adalah simulasi pengukuran antropometri untuk mengidentifikasi gejala / deteksi dini stunting melalui pengukuran tinggi badan menggunakan microtoice, pengukuran berat badan menggunakan timbangan digital yang disediakan oleh pengabdi dan dipraktekkan oleh kader hingga benar-benar mandiri dan mampu melakukan sendiri secara tepat. Kemudian hasil pengukuran disandingkan dengan standar baku WHO NCHS untuk menilai kondisi anak sesuai jenis kelamin dan umur apakah tergolong beresiko stunting atau tidak.

5. Pendampingan

Tahap II Tim Pengabdi melakukan pendampingan oleh enumerator terlatih yang dilaksanakan dari tanggal 13, 20 dan 24 September 2019. Metode yang digunakan adalah mendampingi kader sesuai jadwal di masing-masing Posyandu guna menindaklanjuti hasil pelatihan yang telah berlangsung sebelumnya dengan menggunakan lembar monitoring. Pendampingan dilakukan berdasarkan tahapan tindakan pengukuran antropometri yang baik dan benar. Hasil evaluasinya per kunjungan diisi sesuai yang termuat dalam checklist yang dibagikan kepada enumerator.

Tanggal 24 September dilakukan ujian post test praktikum dengan menggunakan instrument penilaian berupa daftar checklist Deteksi Dini Stunting. Kegiatan simulasi dianggap berakhir dengan menguji kelompok dengan checklist semua kelompok atas kemandirian dalam melaksanakan Deteksi dini stunting. Pendampingan dilakukan didasarkan pada budaya setempat sehingga hasil yang didapatkan sesuai dengan kondisi dan aspirasi masyarakat (Santi et al., 2019).

Hasil pengumpulan data yang dilakukan saat pengabdian masyarakat di Desa Larike, pengetahuan responden tentang Stunting sebelum dan sesudah pendampingan seperti terlihat pada tabel berikut : 
Tabel 2. Pengetahuan Kader Tentang Stunting Sebelum dan Setelah Pendampingan Desa Larike

\begin{tabular}{llccccc}
\hline \multirow{2}{*}{ No. } & \multirow{2}{*}{ Pengetahuan } & \multicolumn{2}{c}{ Sebelum } & \multicolumn{2}{c}{ Sesudah } & P Value \\
& & $\Sigma$ & $\%$ & $\sum$ & $\%$ & \\
\hline 1. & Baik & 1 & 5 & 19 & 95 & \\
2. & Kurang & 19 & 95 & 1 & 5 & $0,000^{*}$ \\
& Total & 20 & 100.0 & 20 & 100 & \\
\hline
\end{tabular}

*Wilcoxon Signed Rank Test

Tabel 2 menunjukkan bahwa pengetahuan Kader Desa Larike sebelum diberikan penyuluhan kesehatan tentang Stunting terjadi peningkatan, yang terbanyak pada tingkatan pengetahuan kurang saat pre test yaitu 19 orang (95\%). Sedangkan setelah diberikan penyuluhan kesehatan yang terbanyak pada tingkatan pengetahuan baik yaitu 19 orang (95\%). Secara statistik menggunakan uji Wilcoxon Signed Rank Test menunjukan bahwa terdapat perubahan pengetahuan sebelum dan sesudah pendampingan kader di Desa Larike

3. Pihak-Pihak yang terlibat

Adapun pihak-pihak yang terlibat dalam kegiatan Pengabdian Masyarakat di Desa Larike Kecamatan Leihitu Barat Kabupaten Maluku Tengah yang dilaksanakan dari bulan Agustus Oktober 2019, antara lain:

a. Kepala Desa Larike Kabupaten Maluku Tengah

b. Kepala Puskesmas Negeri Lima Kabupaten Maluku Tengah

c. Para Saniri Negeri Desa Larike Kabupaten Maluku Tengah

d. Pemuka Agama (Imam Mesjid Kasuari), Tokoh Pemuda, Tokoh masyarakat Desa Larike

e. Kepala Pusat Penelitian dan Pengabdian Masyarakat Poltekkes Kemenkes Maluku

4. Luaran yang Dicapai

Setelah dilakukan kegiatan pengabdian kepada masyarakat dalam bentuk Program Kemitraan Masyarakat bagi kader kesehatan yang dilaksanakan selama bulan September 2019, maka luaran yang dicapai yaitu :

1. Tersedianya media audiovisual berupa film dan leaflet tentang stunting

2. Pengetahuan kader tentang Stunting Desa Larike meningkat setelah diberikan penyuluhan dalam bentuk ceramah, pembagian leaflet, pemutaran video serta pendampingan gizi.

3. Meningkatnya ketrampilan kader dalam penanganan stunting, melakukan pengukuran TB\&BB, perhitungan IMT, cara mengenal ciri utama yang terfokus pada balita untuk pencegahan kejadian stunting.

4. Mendapat dukungan dari semua pihak yaitu Kepala Pemerintahan Desa Larike beserta semua jajarannya dalam penanganan Stunting melalui brainstorming dan akan ditindaklanjuti dalam bentuk kegiatan pencegahan stunting yang akan berjalan secara berkala setiap bulannya oleh KPM (Komite Pemberdayaan Masyarakat) Desa Larike.

\section{KESIMPULAN}

Setelah dilakukan kegiatan pengabdian kepada masyarakat dalam bentuk Program Kemitraan Masyarakat bagi kader Posyandu Desa Larike bahwa telah terciptanya komitmen bersama para perangkat Desa untuk penanganan stunting dengan dibuatkannya badan KPM (Komite Pemberdayaan Masyarakat), pengetahuan dan ketrampilan Kader Kesehatan Desa Larike mengalami peningkatan melalui pelatihan menggunakan media audiovisual yaitu pembagian leaflet dan pemutaran video stunting serta pendampingan gizi.

Dalam rangka peningkatan kualitas hasil pelaksanaan kegiatan pengabdian kepada masyarakat khususnya program kemitraan masyarakat ini perlu disarankan beberapa hal yaitu 
perlunya tindaklanjut dan evaluasi kegiatan penanganan stunting agar bisa lebih efektif dan efisien serta perlu adanya pelatihan fasilitator dari tenaga kesehatan yang bertugas di Pustu Larike selaku staf kontrol sehingga kegiatan penanganan stunting dapat dilakukan secara rutin dan dimonitor dengan tim pengabmas dari Poltekkes Kemenkes Maluku

\section{UCAPAN TERIMA KASIH}

Ucapan terima kasih diucapkan kepada Politeknik Kesehatan Kemenkes Maluku sebagai pihak pemberi dana yang bersumber dari DIPA / RK-AKL Politeknik Kesehatan Kemenkes Maluku.

\section{DAFTAR PUSTAKA}

Badan Penelitian dan Pengembangan Kemenkes RI. Hasil utama Riskesdas 2018. Jakarta: Kementerian Kesehatan Republik Indonesia; 2018.

Brown JE. Nutrition through the life cycle. USA: Thomson-Wadsworth; 2005.

Cairncross S. Linking toilets to Stunting. In: UNICEF ROSA 'Stop Stunting' Conference. New Delhi; 2013.

Dewi M, Aminah M. Pengaruh edukasi gizi terhadap feeding practice ibu balita Stunting usia 6-24 bulan. Indonesian Journal Human Nutrition. 2016;3(1):1-8.

Irianto, M,D. (2013). Hand Out Kesehatan Dan Gizi II. Bandung.

Laporan PKL Desa Terpadu Poltekkes Kemenkes Maluku. 2019. Poltekkes Kemenkes Maluku. Ambon

Notoatmodjo S. Pendidikan dan perilaku kesehatan. Jakarta: Rineka Cipta; 2003.

Rahmawati I, Sudargo T, Paramastri I. Pengaruh penyuluhan dengan media audiovisual terhadap peningkatan pengetahuan, sikap, dan perilaku ibu balita gizi kurang dan buruk di Kabupaten Kotawaringin Barat Propinsi Kalimantan Tengah. Jurnal Gizi Klinik Indonesia. 2007;4(2).

Rikiy dan Yayi suryo prabandari (2013) Motivasi kader posyandu lansia di wilayah kerja puskesmas panarung kecamatan pahandut kota palangka raya provinsi kalimantan tengah. thesis. UGM. Yogyakarta.

Santi Andriyani, Yushinta Eka Farida, \& DS. Drajad Wibowo. (2019). Pendampingan Guru PAUD Ari-Ari Jepara Dalam Meningkatkan Pembelajaran AUD Berbasis Budaya. Dinamisia : Jurnal Pengabdian Kepada Masyarakat, 3(1), 124-130.

Schmidt CW. Beyond malnutrition: the role of sanitation in stunted growth. Environmental Health Perspective. 2014;122(11):A298-A303.

Sekretariat Wakil Presiden RI. 100 kabupaten/kota prioritas untuk intervensi anak kerdil (Stunting) volume 1. Jakarta; 2017.

Setiana. Teknik penyuluhan dan pemberdayaan masyarakat. Bogor: Ghalia Indonesia; 2005.

Sevilla CG. Research method. Quezon City: Rex Printing Company; 2007.

Saleha S. Perbedaan metode diskusi dengan metode ceramah terhadap pengetahuan kader tentang kesehatan reproduksi remaja. Jurnal Kesehatan. 2009;4:71-8.

Wahyurin, Izka Sofiyya, dkk. 2019. Pengaruh Edukasi Stunting menggunakan metode brainstorming dan audiovisual terhadap pengetahuan ibu dengan anak stunting. Ilmu Gizi IndonesiaISSN 2598-7844. Vol. 02, No. 02 141-146.

World Health Organization. (2013). Stunted growth and development: context, causes and consequences. http://www.who.int/nutrition/childhood_stunting_framework_leaflet_en.pdf diakses pada 23 Mei 2017. 